but not glycogen or galactose, to lactic acid, bone marrow showed carbonic anhydrase, choline esterase and methylglyoxylase activity. The presence of deaminases in bone marrow was reported earlier ${ }^{1}$.

Various metabolites in bone marrow. Rabbit bone marrow contained 50-100 mgm. per cent glycogen; total reducing sugar was 25-33 $\mathrm{mgm}$. per cent, of which 2-4 mgm. per cent was true glucose as determined by means of glucose oxidase (notatin). Fructose was absent. Rabbit bone marrow contained $0.5 \mathrm{mgm}$. per gm. glutathione and $0.08 \mathrm{mgm}$. per gm. ascorbic acid. Citric acid was $3.5 \mathrm{mgm}$. per cent in rabbit, and $5 \mathrm{mgm}$. per cent in rat bone marrow (rat long bones contained $320 \mathrm{mgm}$. per cent citric acid). Nonprotein nitrogen in rabbit bone marrow was $75-$ $100 \mathrm{mgm}$. per cent, polypeptide nitrogen $8.5 \mathrm{mgm}$. per cent, amide nitrogen $75-100 \mathrm{mgm}$. per cent; $2 \cdot 7-3 \cdot 0 \mathrm{mgm}$. per cent amide nitrogen was in the protein-free filtrate.

Metals. Copper, zinc and iron were estimated in rabbit bone marrow. The copper content varied from 0.126 to $0.3 \mathrm{mgm}$. per cent, and exceeded amounts in rabbit blood. Zine was $1 \cdot 37 \mathrm{mgm}$. per cent. Iron in bone marrow was estimated simultaneously with the hæmatin content; it was found that a considerable proportion of rabbit bone marrow iron, sometimes as much as two-thirds, was non-hæmatin iron.

Effect of various agents upon bone marrow metabolism. (a) In vitro. The effect of the following substances in $M / 200$ to $M / 400$ concentration upon the anaerobic glycolysis of rat and rabbit bone marrow was investigated: fluoride, iodoacetate, mustard gas, mustard sulphoxide and sulphone, urethane, dimethyldithiocarbamate, amidopyrine, nitrobenzene, sulphanilamide, hydroquinone. Fluoride and iodoacetate, also mustard gas (confirming earlier work by Needham, Cohen and Barrett ${ }^{2}$ ) and mustard sulphone, but not mustard sulphoxide, all inhibited bone marrow glycolysis. Of the other substances, only amidopyrine had an inhibitory eftect, especially in rat bone marrow.

(b) In vivo. The mode of application, dose and systemic effects of mustard gas, sulphoxide and sulphone in rats and rabbits and their action upon bone marrow glycolysis were reported earlier ${ }^{3}$. Table 3 shows the characteristic changes in acidsoluble and nucleic acid phosphorus in rat bone marrow following treatment with mustard gas and mustard sulphoxide, the latter alone and together with dimethyldithiocarbamate (dimethyldithiocarbamate was introduced into mustard gas studies by G. R. Cameron and H. N. Rydon; Porton Report, 1944). The remarkable 'mustard gas-like' 'action of very small amounts of sulphoxide in combination with dimethyldithiocarbamate, in contrast to the relative inactivity of either of these substances alone, was demonstrated befor $\theta^{3}$, but no study of phosphate distribution was made at that time. Dimethyldithiocarbamate could be replaced in such experiments by diethyldithiocarbamate, but not by ethylcarbamate (urethane).

No striking efrects upon bone marrow glycolysis or nucleic acid phosphorus were observed following prolonged administration to rats of lead salts, sulphasuxidine, urethane or amidopyrine.

The adverse effect of total body exposure to X-rays upon bone marrow metabolism was described recently ${ }^{4}$. On the other hand, direct in vitro irradiation of bone marrow with $20,000 \mathrm{r}$. had no efiect upon glycolysis or nucleic acid phosphorus.
Table 3. Effect of mustard gas and mustard sulphoxide upon acidsoluble and nucleic acid phosphorus in rat bone marrow

\begin{tabular}{|c|c|c|c|}
\hline \multirow{2}{*}{ Treatment } & \multirow{2}{*}{$\begin{array}{c}\text { Days } \\
\text { after } \\
\text { treatment }\end{array}$} & \multicolumn{2}{|c|}{$\begin{array}{l}P \text { in mgm. per } 100 \mathrm{gm} \text {. fresh } \\
\text { weight bone marrow }\end{array}$} \\
\hline & & $\begin{array}{l}\text { Total acid- } \\
\text { soluble P }\end{array}$ & Nucleic acid $\mathrm{P}$ \\
\hline Untreated control & 0 & 88 & 287 \\
\hline $\begin{array}{l}\text { Mustard gas, } 0 \cdot 1 \mathrm{ml} \text {. } \\
4 \% \text { solution in ethyl- } \\
\text { ene glycol ether, cut- } \\
\text { aneous application }\end{array}$ & $\begin{array}{l}2 \\
4 \\
6 \\
8\end{array}$ & $\begin{array}{r}55^{*} \\
111 \\
94 \\
78\end{array}$ & $\begin{array}{l}58^{*} \\
200 \\
240 \\
235 \\
\end{array}$ \\
\hline $\begin{array}{l}\text { Mustard sulphoxide, } \\
0.01 \mathrm{mgm} . / \mathrm{gm} ., \text { subcut- } \\
\text { aneous injection }\end{array}$ & $\begin{array}{l}2 \\
4 \\
6\end{array}$ & $\begin{array}{l}79 \\
80 \\
90\end{array}$ & $\begin{array}{l}247 \\
240 \\
260 \\
\end{array}$ \\
\hline $\begin{array}{l}\text { Mustard sulphoxide, } \\
0 \cdot 01 \mathrm{mgm} \text {./gm., plus } \\
\text { dimethyldithiocarba- } \\
\text { mate, } 0 \cdot 1 \text { mgm./gm., } \\
\text { subcutaneous injection }\end{array}$ & $\begin{array}{l}2 \\
4 \\
6 \\
8\end{array}$ & $\begin{array}{r}58^{*} \\
113 \\
120 \\
98\end{array}$ & $\begin{array}{l}88^{*} \\
240 \\
224 \\
247\end{array}$ \\
\hline $\begin{array}{l}\text { Dimethyldithiocarba- } \\
\text { mate, } 0 \cdot 1 \text { mgm./gm., } \\
\text { subcutaneous in- } \\
\text { jection }\end{array}$ & $\begin{array}{l}2 \\
4 \\
6\end{array}$ & $\begin{array}{l}68 \\
72 \\
78\end{array}$ & $\begin{array}{l}265 \\
250 \\
260\end{array}$ \\
\hline
\end{tabular}

* Bone marrow of grossly altered, fluid consistency, with consider able admixture of blood.

Some of the experiments with mustard gas and its derivatives were carried out as part of extra-mural studies on behalf of the Ministry of Supply; thanks are due to the Chief Scientist, Ministry of Supply, for permission to publish the results. The study of bone marrow metabolism is supported by a personal grant to the author from the Medical Research Council.

${ }^{1}$ Lutwak-Mann, C., Biochem. J., 41, Proc. $\mathrm{xxx}$ (1947).

${ }^{2}$ Needham, D. M., Cohen, J. A., and Barrett, A. M., Biochem. J., 41, 631 (1947).

${ }^{3}$ Lutwak-Mann, C., Report to Ministry of Supply by Dr. Malcolm Dixon, No. 32 (1947).

' Lutwak-Mann, C., and Gunz, F. W., Biochem. J., 44, Proc. iii (1949).

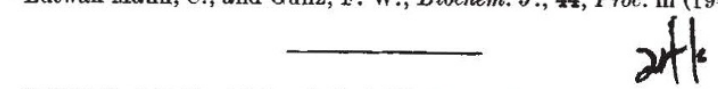

\section{SCIENCE IN ADLYLT EDUCATION}

TWO years ago, at Iftindee the Council of the British Associatigrasked the Education Section to consider frhof pould be done to stimulate more interest in scobe in the sphere of adult education. As a yesut acommittpento explore this question was esthe fished joint 1 y the National Foundation for Adul Educatio find the British Association; and it has recently issued an interim report. One of the sessions of the Education Section of the British Association at the Newcastle meeting was devoted to a discussion of this report.

The discussion was opened by Mr. W. O. Lester Smith, who had been chairman of the joint committee. Emphasizing the interim character of the report, he said that the aim of the committee has been to produce some practical suggestions which might bring early results; they are well aware, however, that there are fundamental issues which require consideration and that there is room for a report of a long-term character. He paid a tribute to the services rendered by Mr. E. M. Hutchinson as secretary of the joint committee, and commented upon the help given by directors of extra-mural departments and secretaries of Workers' Educational Association districts, and also by many tutors, especially those who are actively engaged in promoting courses in scientific studies.

The president of the Education Section, Sir Fred Clarke, was in the chair, and he rightly described the discussion as valuable and helpful. Among the many 
who contributed to the discussion were several members of the joint committee, including $\mathrm{Mr}$. Hutchinson, Prof. Winifred Cullis, Dr. Maxwell Garnett and Dr. P. F. R. Venables. It is clear that the interim report met with general acceptance, and there was a strong feeling that if the Ministry of Education, local education authorities, university extra-mural departments, and voluntary associations like the Workers' Educational Association would implement its recommendations substantial advance would ensue. Mr. Lester Smith remarked upon the whole-hearted way in which the Ministry had cooperated with the joint committee, and commented upon the valuable help given at its meetings by $\mathrm{Mr}$. $H$. R. D'Aeth, an inspector from the Ministry of Education.

The outstanding feature of the discussion was the emphasis upon the need of recruiting for the teaching of science to adult classes suitably qualified tutors with a flair for such work. This crucial need has been stressed before, notably in a report published by the British Association in 1933 on "Science Teaching in Adult Education", and in a report of the Adult Education Committee of the Board of Education in 1927 on "Natural Science in Adult Education". The evidence shows unmistakably that where extra-mural departments have appointed stafi tutors in science there has been healthy advance. For example, in the Cambridge extra-mural area the percentage of classes in natural science subjects has risen in recent years to 16 per cent against a figure of 4.5 per cent for the whole of Great Britain.

Prof. Winifred Cullis observed that in her lifetime she had witnessed a remarkable growth of interest in the biological sciences, and remarked on the appeal that they made to members of women's organisations. Reference was made to a table of "interest ratings" quoted in the report, which show that health has become interest No. 1, followed closely by interest in new developments, the application of science to industry, and psychology; while "fundamentals of physics and chemistry" rank as low as nineteenth. There seemed to be general agreement at this meeting that tutors and discussion-group leaders must be men and women with an appreciation of the implications of science for personal and social life. There was much discussion as to whether current tendencies in university and technical education help to produce that all-round view of science which enables the tutor to interest the inquiring student. Reference was made to the 1944 report of the British Association committee on post-war university education, and to its reminder that "separate specialisms tend to be increasingly divorced from the life of the community". It was contended that an issue like that of population and food, with which Sir John Russell had dealt so cogently in his presidential address, is the kind of topic which should arouse the interest of students in adult education classes. Tutors who can establish a liaison between the natural and social sciences are the most likely to meet with success.

It was decided to invite the co-operation of other sections of the Association in stimulating the study of science in the adult education field; and there was general endorsement of the recommendations of the report, of which the principal ones are: (1) that university extra-mural departments should make stafi appointments of people competent to teach and organise classes in science; (2) that local education authorities should give sympathetic consideration to requests for assistance regarding accommodation, transport of apparatus, and provision of visual aid equipment; (3) that local advisory committees for adult education should foster a liberal approach to vocational studies in colleges of further education; (4) that the Association of Tutors in Adult Education should, through its branch meetings and otherwise, give special attention to the relation in class teaching between the natural and the social sciences.

\section{PSYCHOLOGY AND TEACHING \\ PSYCHOLOGY AND TEACHING}

$\mathrm{T}$

HE final session, on September 7, of Section $J$ (Psychology) of the British Association at the Newcastle upon Tyne meeting was devoted to three papers on ways ip bich psychology and professional psychologis cardentribute to the improvement of teachprg. Mury. Lumsden surveyed the whole field and plinted out thaty yile the aims of education are largely determing dS by non-psychological interests, these aims callot be brought to fruition unless children can be influenced in their development along the desired lines by teachers who have been trained to understand the mental growth of children. By reason of the shortness of the course and the immaturity of the college students, this training can only be simple and general and closely applied to their experience of children. It cannot cover many of the less usual problems of teaching. Therefore, it should be under the direction of a well-qualified psychologist who can not only bring into the college the results of research, but can also impress it on the students that circumstances may arise in which it is no confession of failure to seek advice from a consultant educational psychologist.

Something approaching a school psychological service, staffed by professional educational psychologists, has in some places been developed, and could be elsewhere but for shortage of stafi. Its main function would be to assist teachers who asked for its help on problems of learning and behaviour. It would be a mistake to think its usefulness should be restricted to handicapped children or the maladjusted; one of its functions would be to advise on suitable forms of special education for the former and, in co-operation with the School and National Health Services, to diagnose and treat the latter. Apart from this case-work, such a service could offer useful advice to teachers and authorities on questions of normal educational practice, including examinations and records, and selection of children for different forms of secondary education; on the design and provision of equipment and apparatus ; and, in some such way as the industrial psychologist does in factories, on the influence of working conditions in schools upon efficiency. A school psychological service should also be a channel through which information might reach teachers on the ways in which their classroom work might influence the mental health of the next generation and promote better social and international understanding.

Following this general survey, Miss C. M. McCallum gave a description of the function and aims of one such psychological service-that of Glasgow-which restricts itself to dealing with children who for one reason or another are failures, in school or society. Dealing with three thousand cases annually in twelve clinics, the service trains its own workers, who are all teachers with a postgraduate degree in education and psychology. She traced most failures to an 